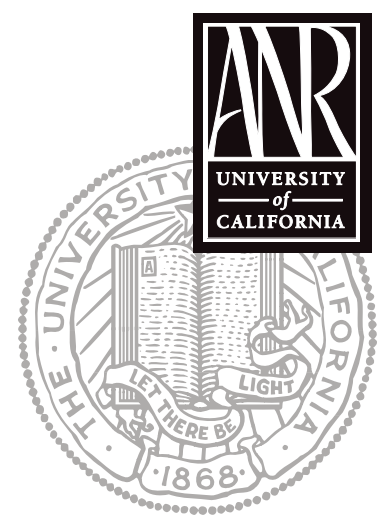

UNIVERSITY OF CALIFORNIA

Division of Agriculture and Natural Resources http://anrcatalog.ucdavis.edu

\title{
Genetic Engineering and Pollen Flow
}

NORMAN C. ELLSTRAND, Professor of Genetics and Director, Biotechnology Impacts Center, University of California, Riverside

Pollen grains are the vehicles that transport a plant's male gametes. For plants that produce pollen, it is transported by wind and insects. Also, many species can pollinate some of their own flowers. Typically, the majority of the pollen grains produced by an individual plant move a very short distance. But if hundreds, thousands, or millions of plants are all creating pollen, the tiny fraction that goes a relatively long distance is multiplied accordingly. In the case of wind-pollinated plants that pollinate other plants (outcross), it is not unusual for viable pollen grains to be found more than $1 / 2$ mile $(800 \mathrm{~m}$ ) from their source (Ellstrand 2003a).

Long-distance gene flow occasionally occurs in many plant species, including cultivated plants (Kelly and George 1998). For traditionally improved plants, most cases of gene flow have been of little consequence. Rarely, gene flow can provide benefits; a few spontaneous hybrids have been adopted as new cultivars. In some cases, gene flow has lead to problems (see Ellstrand 2003a). Therefore, concerns have been raised about the possibility of pollen flow from genetically engineered (GE) crops into plant populations for which they are not intended. As stated in a recent National Research Council (2004) report, engineered gene flow "is not expected to be a problem, in and of itself, unless it leads to undesirable consequences." Let's take a look at what those consequences might be.

A great deal of attention has been focused on engineered crop genes in natural populations. For guidance about future problems with GE crops, we can ask whether traditionally improved crops have hybridized with wild relatives, and if so, whether those hybrids have caused any problems. Most cultivated species naturally hybridize with some wild relative or relatives somewhere in the world (Ellstrand 2003a). In some cases, such as coffee, those wild relatives are geographically restricted. On the other hand, one or more wild relatives of rice are usually found where rice is cultivated worldwide. Most cases of natural hybridization between cultivated plants and their wild relatives have been of little consequence. On occasion, such hybridization has created two classes of problems:

- The evolution of new or more difficult-to-control weeds. In particular, the evolution of a new weed beet in Europe, a hybrid of sugar beet and an innocuous wild species, has resulted in well over a billion dollars' damage to Europe's sugar industry in terms of reduced yields and increased management costs (Ellstrand 2003a).

- Increased extinction risks for wild relatives. In Taiwan, gene flow from cultivated rice has played an important role in the extinction of a wild relative (Kiang et al. 1979).

\section{Are there examples of gene flow from GE crops to wild relatives?}

Among the current commercialized GE crops that are or could be grown in California, only canola has cross-compatible wild relatives. GE herbicide-resistant canola has already naturally hybridized with a weedy relative in Quebec (Warwick et al. 2003). In fact, it is as yet the only case known in which engineered genes from a commercial 
crop have been found in natural populations. Whether or not these hybrid populations are becoming a problem is currently under study by the group that discovered them.

Dozens of other GE species have been the object of field trials in California. Some of these have wild relatives in the state, including feral populations, and others do not. Plants grown under field trial conditions should be managed in such a way as to prevent their pollen from fertilizing other plants. However, pollen from GE herbicide-resistant creeping bentgrass grown in field trials in Oregon successfully fertilized plants in wild populations of the same species, as well as those of a weedy relative, several miles from the test plots (Watrud et al. 2004). This event represents the only known case to date of the movement of engineered genes from a field test into natural populations.

Much less discussed, but much more likely, is unintended pollen flow from GE plants into other fields of the same crop. Likewise, many crops have "gone wild," occurring as feral populations (see Gressel 2005 for many examples); these too could serve as repositories for engineered genes. In this case, the pollen source and pollen recipient are usually highly sexually compatible. Strict guidelines have been developed and followed for the last century to spatially and temporally isolate different stands of the same crop (see CCIA 2003). These have been created with the goal of obtaining a certain level of genetic purity for breeding and commercial purposes with the recognition that $0 \%$ adventitious presence (AP) is often impossible under field conditions.

\section{What are the possible consequences of gene flow from GE crops to other cultivars?}

The problems voiced about unintended gene flow from a GE crop to another crop of the same species include

- loss of security of intellectual property.

- nontarget effects on organisms in natural or agricultural ecosystems.

- evolution of new weeds, such as the case of multiple-herbicide-resistant canola (Hall et al. 2000). In that case, the new weed is still controllable, but requires a different herbicide than what is usually used on canola volunteers.

- "Genetic pollution" of crops intended to have a level of purity with regard to market demands, such as crops intended to be organic or intended to be sold to a foreign market that does not tolerate the presence of materials from GE plants.

- Possible health effects from genes engineered to produce pharmaceutical or industrial compounds if these plants enter the food or feed supply (see Ellstrand 2003b). Such plants are grown only under stringent field test regulations or in contained facilities such as greenhouses. However, lack of compliance can create opportunities for such genes to move.

The possibility of these and other potential problems has focused attention on creating new methods (Genetic Use Restriction Technologies, or GURTs) for containing pollen and seed from GE organisms. Many of these methods involve genetic alterations with the goal of reducing or preventing the unintended transmission of transgenes from one generation to the next. Most of these novel techniques are in the early stages of development (NRC 2004).

\section{PERSPECTIVE}

The successful prevention of problems due to flow of pollen or seed requires a mindful approach to consideration of the organism to be engineered, the specific trait to be engineered, whether the engineered organism should be grown outside, and, if so, the distribution of its wild and cultivated relatives. Guidelines have been developed to aid in decisions about whether and how to field-release GE plants (e.g., Christensen et al. 
2005; Colorado Institute of Public Policy 2004; NRC 2004; Rissler and Mellon 1996; Scientists' Working Group on Biosafety 1998; Strayer 2002). Furthermore, the agencies that regulate GE plants take a case-by-case approach with their decisions; the consideration of the likelihood of gene flow and its potential consequences are generally given a high priority. For example, while certain engineered crops have been fully deregulated, others, such as those that produce industrial compounds (e.g., pharmaceuticals) currently must be grown under permit (Federal Register 2005).

\section{REFERENCES}

CCIA (California Crop Improvement Association). 2003. Seed certification standards in California. CCIA Web site, http://ccia.ucdavis.edu/CCIA/standards_ frame.htm,

Christensen, P. J., M. K. Misra, S. Rai, Y-Y Shyy, and J. D. Wolt. 2005. Confined production processes for non-food corn. Ames: Iowa State University Biosafety Institute for Genetically Modified Agricultural Products.

Colorado Institute of Public Policy. 2004. Bio-pharming in Colorado: A guide to issues for making informed choices. Fort Collins: Colorado Institute of Public Policy.

Ellstrand, N. C. 2001. When transgenes wander, should we worry? Plant Physiology 125:1543-1545.

- 2003a. Dangerous liaisons? When cultivated plants mate with their wild relatives. Baltimore: Johns Hopkins University Press.

_ 2003b. Going to "Great Lengths" to prevent the escape of genes that produce specialty chemicals. Plant Physiology 132:1770-1774.

Ellstrand N. C., H. C. Prentice, and J. F. Hancock. 2002. Gene flow and introgression from domesticated plants into their wild relatives. In M. Syvanen and C. I. Kado, eds., Horizontal gene transfer. 2nd ed. San Diego: Academic Press. 217-236.

Federal Register. 2005. Introductions of plants engineered to produce industrial compounds. Docket No. 03-038-2. Affirmation of interim rule as final rule. 7 CFR Part 340. Published May 4, 2005. 70 FR 23009-23011.

Gressel J. 2005. Crop ferality and volunteerism. Boca Raton: CRC Press.

Hall, L., K. Topinka, J. Huffman, L. Davis, and A. Allen. 2000. Pollen flow between herbicide-resistant Brassica napus is the cause of multiple-resistant B. napus volunteers. Weed Science 48:688-694.

Kelly, A. F., and R. A. T. George. 1998. Encyclopaedia of seed production of world crops. Chicester: John Wiley and Sons.

Kiang, Y. T., J. Antonovics, and L. Wu. 1979. The extinction of wild rice (Oryza perennis formosana) in Taiwan. Journal of Asian Ecology 1:1-9.

NRC (National Research Council). 2002. Environmental effects of transgenic plants: The scope and adequacy of regulation. Washington, DC: National Academy Press.

- 2004. Biological confinement of genetically engineered organisms. Washington, DC: National Academy Press.

Rissler, J., and M. Mellon. 1996. The ecological risks of engineered crops. Cambridge, MA: MIT Press.

Scientists' Working Group on Biosafety. 1998. Manual for assessing ecological and human health effects of genetically engineered organisms. Edmonds, WA: The Edmonds Institute. 
Strayer, D. 2002. Identity preserved systems: A reference handbook. Boca Raton: CRC Press.

Warwick, S. I., M-J Simard, A. Légère, H. J. Beckie, L. Braun, B. Zhu, P. Mason, G. Séguin-Swartz, and C. N. Stewart. 2003. Hybridization between transgenic Brassica napus L. and its wild relatives: Brassica rapa L., Raphanus raphanistrum L., Sinapis arvensis L., and Erucastrum gallicum (Willd.) O.E. Schulz. Theoretical and Applied Genetics 107:528-539.

Watrud, L., E. H. Lee, A. Fairbrother, C. Burdick, J. R. Reichman, M. Bollman, M. Storm, G. King, and P. K. van den Water. 2004. Evidence for landscapelevel, pollen-mediated gene flow from genetically modified creeping bentgrass with CP4 EPSPS as a marker. Procedings of the National Academy of Sciences 101:14533-14588.

To order or obtain printed ANR publications and other products, visit the ANR Communication Services online catalog at http://anrcatalog.ucdavis.edu. You can also place orders by mail, phone, or FAX, or request a printed catalog of our products from:

University of California

Agriculture and Natural Resources

Communication Services

6701 San Pablo Avenue, 2nd Floor

Oakland, California 94608-1239

Telephone: (800) 994-8849 or (510) 642-2431

FAX: (510) 643-5470

E-mail inquiries: danrcs@ucdavis.edu

An electronic version of this publication is available on the ANR Communication Services Web site at http://anrcatalog.ucdavis.edu.

Publication 8182

(C) 2006 by the Regents of the University of California, Division of Agriculture and Natural Resources. All rights reserved.

The University of California prohibits discrimination or harassment of any person on the basis of race, color, national origin, religion, sex, gender identity, pregnancy (including childbirth, and medical conditions related to pregnancy or childbirth), physical or mental disability, medical condition (cancer-related or genetic characteristics), ancestry, marital status, age, sexual orientation, citizenship, or status as a covered veteran (covered veterans are special disabled veterans, recently separated veterans, Vietnam era veterans, or any other veterans who served on active duty during a war or in a campaign or expedition for which a campaign badge has been authorized) in any of its programs or activities. University policy is intended to be consistent with the provisions of applicable State and Federal laws.

Inquiries regarding the University's nondiscrimination policies may be directed to the Affirmative Action/Staff Personnel Services Director, University of California, Agriculture and Natural Resources, 1111 Franklin Street, 6th Floor, Oakland, CA 94607-5201, (510) 987-0096. For a free catalog of other publications, call (800) 994-8849. For help downloading this publication, call (530) 754-5112.

This publication has been anonymously peer reviewed for technical accuracy by University of California scientists and other qualified professionals. This review process was managed by the ANR Associate Editor for Agronomy and Range Science.

pr-3/06-SB/CR

ISBN 978-1-60107-400-3 